\section{Noen av verdens mest neglisjerte sykdommer}

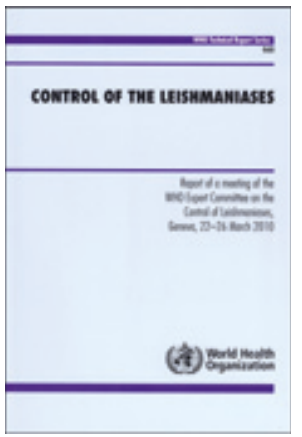

Verdens helseorganisasjon

Control of the leishmaniases

Report of a meeting of the WHO expert committee on the control of leishmaniases, Geneva, 22-26 March 2010. 186 s, tab, ill. Genève: WHO, 2010. Pris CHF 25 ISBN 978-92-4-120949-6

Dette heftet inngår i WHO Technical Report Series (en oppdatering av 1990-utgaven) og er en lærebok for dem som skal planlegge og gjennomføre kontrolltiltak mot leishmaniasis. Kapitlene tar for seg historie, leishmaniasis hos mennesker (med oppdatert fylogeni for de forskjellige leishmaniaartene), diagnose og behandling, omfanget av sykdommen, kontrollstrategier i geografisk perspektiv, organisering av kontroll, internasjonal koordinering, opplæring, forskning og anbefalinger. Bortsett fra rikholdige tabeller er det svært sparsomt med illustrasjoner.

Kapitlet om diagnose og behandling er det mest relevante for leger i Norge: Leismaniasis har mangesidige kliniske bilder, fra enkle kutane lesjoner til svære mukokutane manifestasjoner, og visceral leishmaniasis. Det har tilkommet mye nytt innen hurtigdiagnostikk og terapianbefalinger siden 1990, og pasienter med immunsvikt/hiv innebærer nye problemer.

Noen leishmaniaarter er zoonoser, som Leishmania (Viannia) brasiliensis complex og L mexicana, mens andre har mennesker som smittereservoar, for eksempel L donovani. Vektorene er sandfluer, som i den gamle verden tilhører slekten Phlebotomus, og i den nye verden både Phlebotomus og Lutzomyia, men man vet ikke hvilke, og hvor mange, av de 464 hittil beskrevne neotropiske sandfluearter som kan være vektorer for Leishmania spp., og man har nok langt fra noen fullstendig liste og hvilke pattedyrarter som kan opptre som reservoar.

Det er slående hvor mye man ikke vet om effekten av tradisjonelle kontrolltiltak, som myggnett og spraying med insekticider i hus og på husdyr. Sandfluer biter om ettermiddagen, og innendørs spraying kan ha effekt når det dreier seg om sandfluearter som oppholder seg innendørs, men ellers ikke. Spraying på husdyr og i fjøs kan i verste fall føre til at sandfluene biter menneskene i stedet. Det er holdepunkter for at det å ødelegge smågnagerganger rundt husene kan være effektivt for å redusere steder hvor larvene kan utvikle seg. Kontroll av smittereservoarene er vanskelig. Mennesker kan være smittebærere etter fullført behandling, særlig hivinfiserte individer. Skyting av løshunder har vært forsøkt, men med usikker effekt. Tamhunder må behandles, og kontrolleres, da sykdommen kan blusse opp igjen. Når det gjelder ville pattedyrverter vil også kontrolltiltak komme på tale, men det å skape minst 300 meters avstand fra menneskeboliger til skogen er mer effektivt. Boken vier stor plass til de forskjellige leishmaniaartenes geografiske utbredelse, og forskjeller i integrerte kontrollstrategier som må skreddersys etter hvor man er, både når det gjelder behandling/ overvåking, vektorkontroll og eventuelt kontroll av ville vertsdyr.

Ca. 350 millioner mennesker lever i områder hvor leishmaniasis forekommer, og det er ca. to millioner tilfeller og 50 000-60 000 dødsfall årlig. Fattigdom øker risikoen for leishmaniasis gjennom trangboddhet, dårlige hus og sanitærforhold, økt hivprevalens, underernæring og ved at fattige ofte bor nær natur og husdyr. I det store perspektivet er det fattigdommen som må bekjempes.

\section{Tankevekkende kritikk av psykiatrisk behandling}

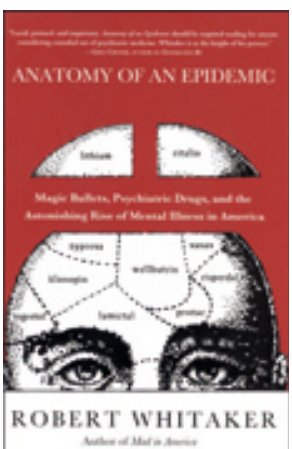

\section{Robert Whitaker Anatomy of an epidemic}

Magic bullets, psychiatric drugs, and the astonishing rise of mental illness in America. 404 s, tab, ill. New York, NY: Crown Publishers, 2010. Pris USD 26 ISBN 978-0-307-45241-2

Introduksjonen av nevroleptika i midten av 1950-årene oppfattes ofte å ha revolusjonert psykiatrien og tilbudet til mennesker med alvorlige psykiske lidelser. Senere har utvikling av antidepressiver og stemningsstabiliserende medisin støttet opp om en forståelse av at medikamenter bidrar til å helbrede psykiske lidelser. Psykiatriske pasienter synes likevel ikke å bli friske slik de gjør i andre deler av medisinen hvor det har vært store farmakologiske fremskritt. Tvert imot: Antall personer som er uføretrygdet grunnet psykiske lidelser er blitt nesten tredoblet de siste to tiårene. Og hvorfor går det bedre for pasienter med diagnostisert schizofreni i utviklingsland enn i industrialiserte land? Dette er noen av problemstillingene Robert Whitaker belyser.

I motsetning til mye annen psykiatrikritikk tar forfatteren utgangspunkt i anerkjent psykiatrisk forskning og historisk dokumentasjon. Han stiller spørsmål ved om medikamentell psykiatrisk behandling er med på å bedre helsetilstanden til mennesker med psykiske lidelser eller om den tvert imot bidrar til en kronifisering av lidelsene.

Whitaker viser hvordan utviklingen av dagens kriteriebaserte diagnostikk passer som hånd i hanske med markedsføring av lidelsesspesifikke medikamenter, og hvordan dette igjen bidrar til en forståelse av at psykiske plager best kan beskrives og forstås som hjerneorganiske lidelser. Dette til tross for at omfattende nevrobiologisk forskning ikke har greid å bekrefte de sentrale teoriene på dette området. At medikamenter faktisk kan ha god symptomatisk effekt på psykiske lidelser, bør likevel kunne begrunne vår tids omfattende forskrivning av psykofarmaka. Forfatterens litteraturgjennomgang viser imidlertid at det er mange holdepunkter for at det på lang sikt går bedre med pasienter som ikke bruker medikamenter. Det dokumenteres at omfanget av bivirkninger av psykofarmaka ofte er dårlig kjent og i stor grad tones ned, spesielt ved introduksjon av nye medikamenter. Han sannsynliggjør hvordan tette bånd mellom farmasøytisk industri og personer innenfor det psykiatriske fagmiljøet bidrar til dette.

Robert Whitaker har bakgrunn som forfatter og prisbelønnet helsejournalist. Boken bærer preg av at han har omfattende oversikt over den relevante psykiatriske forskningen. Samtidig evner han å sammenstille ulike funn og data på en ny og utfordrende måte. Anatomy of an epidemic er godt skrevet, gjennomarbeidet og grundig. Grunnlagsmaterialet er dessuten samlet og ligger lett tilgjengelig på nettet (www.madinamerica.com). Hans funn og konklusjoner underbygges og illustreres med historiene til en rekke personer med ulike erfaringer fra psykiatrisk behandling som forfatteren har intervjuet.

Selv om det er amerikanske forhold som blir beskrevet, bygger også norsk psykiatri i stor utstrekning på den samme faglige forståelsen. Boken representerer et betimelig korrektiv for fagfeltet. Den anbefales for både fagfolk, helsepolitikere og brukere av psykiatriske helsetjenester. 